\title{
CHANGES IN SELECTED BLOOD INDICES OF COMMON CARP AFTER ACUTE EXPOSURE TO CADMIUM
}

\author{
M. WITESKA \\ Department of Animal Physiology, Siedlce Lniversity, Poland
}

Received July 22, 1998

Accepted September 21, 1998

\begin{abstract}
Witeska, M.: Changes in Selected Blood Indices of Common Carp after Acute Exposure to Cadmium. Acta vet. Brno 1998, 67: 289-293.

Haematocrit. red and white blood cell count. phagocytic index. and viability of lymphocytes were studied in common carp exposed for $3 \mathrm{~h}$ to $10 \mathrm{mg} \mathrm{dm}^{-3}$ of cadmium. Hematocrit value and RBC count were elevated in all Cd-exposed $(n=10)$ and control fish $(n=10)$, compared to those sampled directly from the rearing tank (non-stressed). This finding indicates that the changes were caused mainly by manipulation stress, and no clear effect of cadmium on red blood cell was observed.

White blood cell count was lowered after 48 and $96 \mathrm{~h}$ from the end of $\mathrm{Cd}$ exposure suggesting an immunological suppresion.

Phagocytic response was significantly $(\mathrm{P}<0.05)$ depressed in all stressed fish, and showed also some cadmium-induced elevation, up to $48 \mathrm{~h}$ from the end of the exposure. Later a decrease was observed.

Preliminary results of lymphocyte viability analysis suggest some supression in $96 \mathrm{~h}$. Only 6 out of 10 fish survived $96 \mathrm{~h}$ after the end of exposure which indicates disturbances in physiological functions in fish which were not clearly expressed in their blood.
\end{abstract}

Toxicology, red blood count, white blood count, phagocytic index, viability of lymphocytes

Cadmium is extremely toxic to aquatic organisms, and tends to accumulate in living organisms. Cadmium concentration in the water may range from undetectable level (non-polluted water) to $4 \mathrm{mg} \cdot \mathrm{dm}^{-3}$ (strongly contamined mine effluents) (Dojlido 1995). It is readily absorbed by the fish from water, and concentrated in their bodies (Houston and Keen 1984). Among various disturbances, cadmium may affect blood parameters of fish such as numbers blood of cells (Ruparelia et al. 1990; Gill and Epple 1993) as well as their function (Viola et al. 1996).

The aim of the present study was an assessment of the influence of short-term cadmium exposure on selected blood indices of common carp fingerlings.

\section{Materials and Methods}

Common carp ( C.prinus carpio L.) fingerlings of average body mass $75 \mathrm{~g}$ were harvested from the ponds at the beginning of October 1997, and kept under laboratory conditions in the water recirculation system for 6 weeks. Then they were exposed for $3 \mathrm{~h}$ to $10 \mathrm{mg} \cdot \mathrm{dm}^{-3}$ of cadmium in the water of total hardness $162 \mathrm{mg} \mathrm{CaCO}_{3} \mathrm{dm}^{-3}$, at $17^{\circ} \mathrm{C}$. After the exposure, the fish were transferred to metal-free water.

Blood was sampled from the heart immediately after exposure ( $\mathrm{Cd} 0)$. and 24, 48, 72, and $96 \mathrm{~h} \operatorname{later}(\mathrm{Cd} 24, \mathrm{Cd} 48$, $\mathrm{Cd} 72$, and $\mathrm{Cd} 96$, respectively). Blood sampled from the non-exposed fish (taken directly from the rearing tank $\mathrm{K} 0$ ), and from the fish exposed in the same way as Cd-treated ones, but in metal-free water (K), were used as controls. Blood from 10 fish of each group was analyzed, except for Cd96, in which only 6 fish survived.

Haematocrit, red and white blood cell count, phagocytic activity (NBT test), and viability of lymphocytes were assessed. Phagocytic activity of neutrophils and monocytes was estimated using nitroblue tetrazolium reduction test: blood was mixed with p-nitro blue tetrazolium chloride solution. incubated for $1 \mathrm{~h}$ at $28{ }^{\circ} \mathrm{C}$, and $\mathrm{DMF}$ was added. After centrifugation, the absorbance was measured at $540 \mathrm{~nm}$. 
Viability of blood, spleen, and kidney lymphocytes was evaluated using trypan blue staining. Ground tissues were suspended in Hanks solution, layered on Gradisol, Polfa Kutno $\left(1.077 \pm 0.001 \mathrm{~g} \mathrm{~cm}^{-3}\right)$ and centrifuged. Then the lymphocyte layer was collected, and lymphocytes were washed twice in Hanks solution at 1000 rpm. Trypan blue solution was added and lymphocytes were counted in Bürker chamber. Percentage of dead cells (staining blue) was calculated for 1 or 2 fish of each group.

The results were evaluated using Duncan's test.

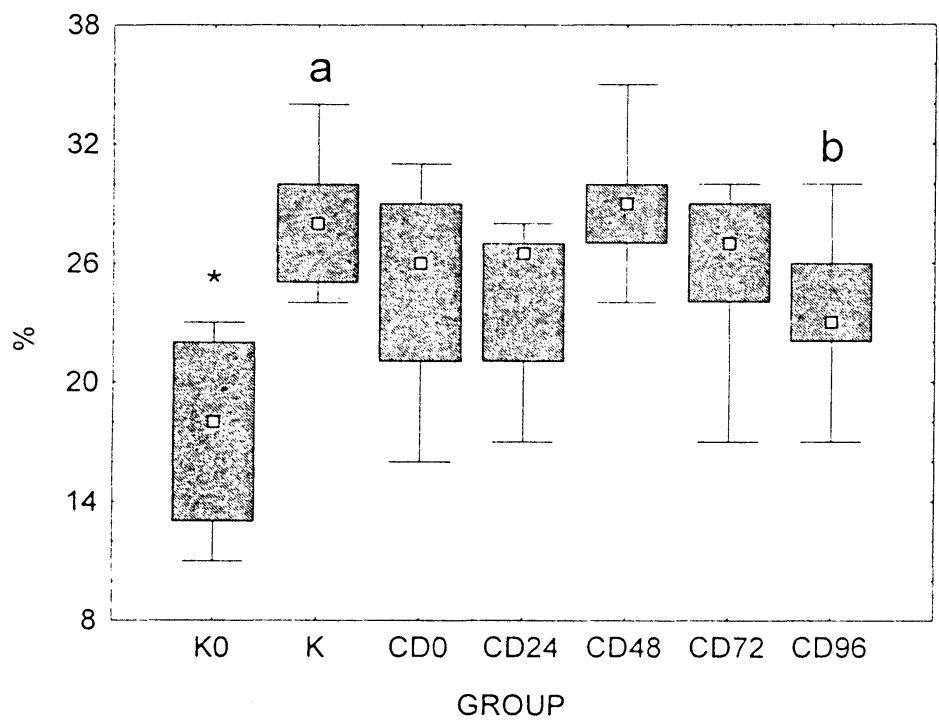

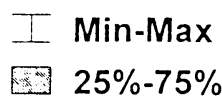

- Median value

Fig. 1. Changes in haematocrit in common carp after $3 \mathrm{~h}$ exposure to $10 \mathrm{mg} \mathrm{dm}^{-3}$ of cadmium *different from all other values and $\mathbf{a}$ different from $\mathbf{b}$ at $\mathrm{P}<0.05$

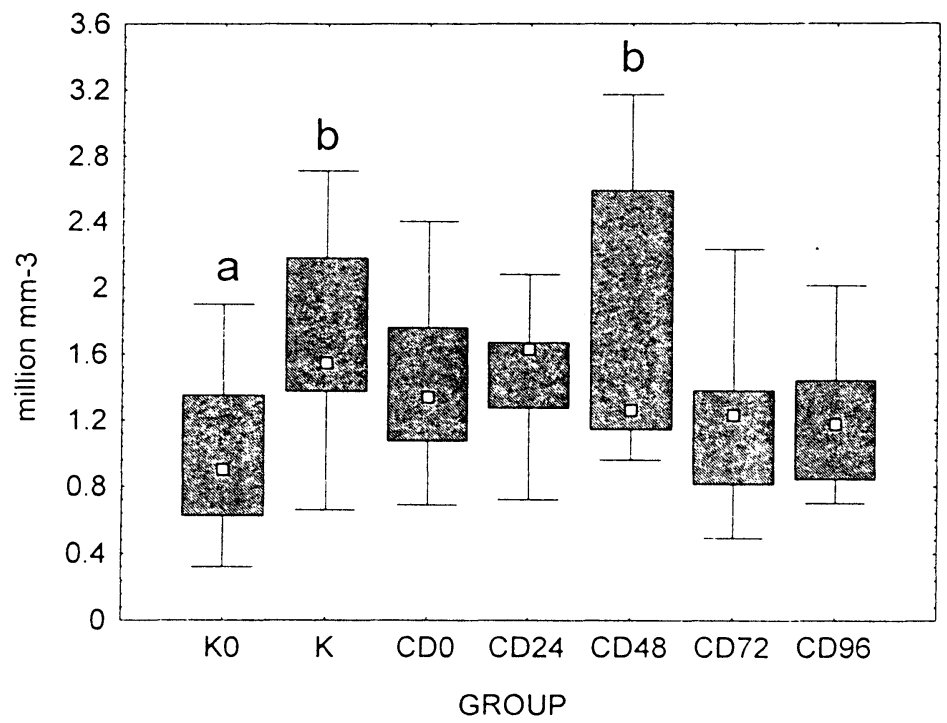

I Min-Max

$25 \%-75 \%$

- Median value

Fig. 2. Red blood cell count in common carp after $3 \mathrm{~h}$ exposure to $10 \mathrm{mg} \mathrm{dm}^{-3}$ of cadmium *different from all other values and $\mathbf{a}$ different from $\mathbf{b}$ at $\mathrm{P}<0.05$ 


\section{Results and Discussion}

Haematocrit value (Fig. 1) was significantly $(\mathrm{P}<0.05)$ increased in all exposed groups, including control K, and red blood cell count (Fig. 2) was elevated in the control K, and $\mathrm{Cd} 48$, compared to non-exposed fish (K0). These changes were a typical stress response indicating manipulation stress, and no cadmium-induced disturbances. Cadmium was reported

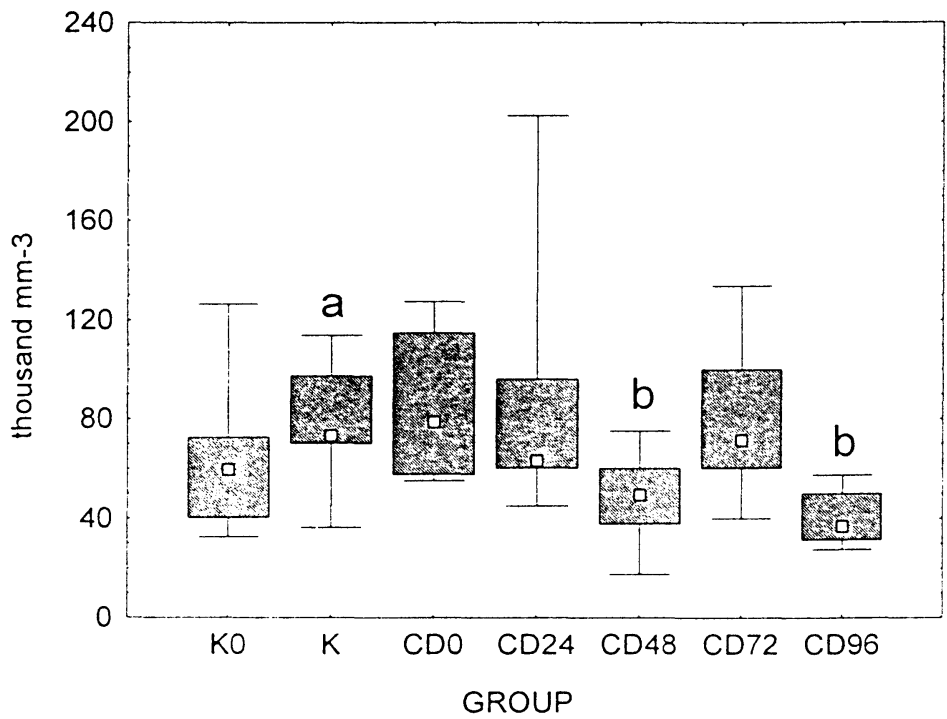

I. Min-Max

$25 \%-75 \%$

- Median value

Fig. 3. White blood cell count in common carp after $3 \mathrm{~h}$ exposure to $10 \mathrm{mg} \mathrm{dm}^{-3}$ of cadmium *different from all other values and $\mathbf{a}$ different from $\mathbf{b}$ at $\mathrm{P}<0.05$

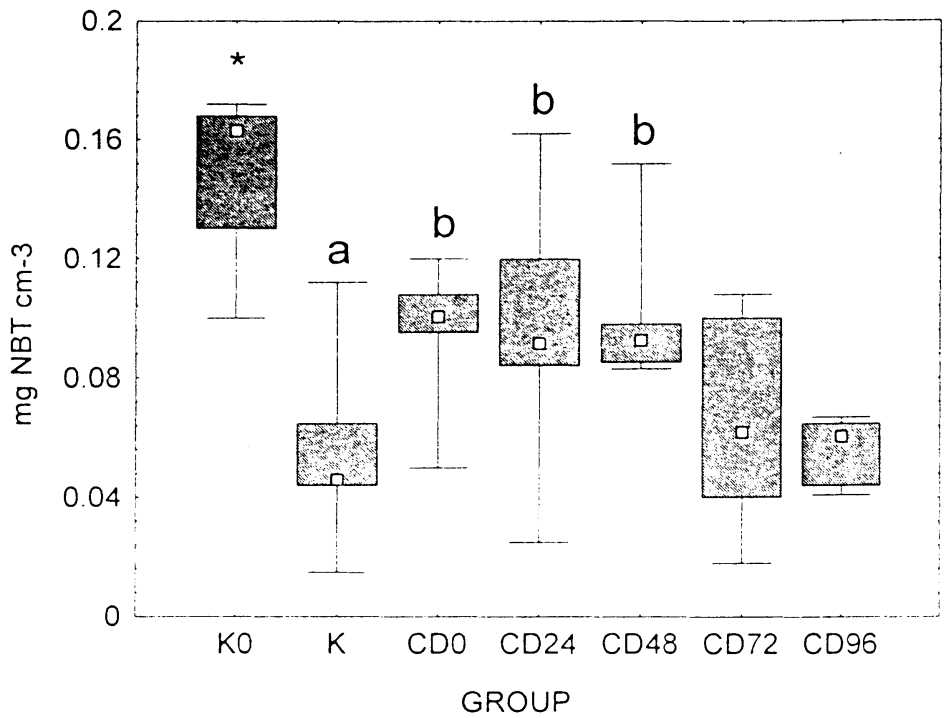

I Min-Max $25 \%-75 \%$

- Median value

Fig. 4. Phagocytic index (NBT) in common carp after $3 \mathrm{~h}$ exposure to $10 \mathrm{mg} \mathrm{dm}^{-3}$ of cadmium *different from all other values and $\mathbf{a}$ different from $\mathbf{b}$ at $\mathrm{P}<0.05$ 
to produce enhanced erythropoiesis ( Sarav an and Natarajan 1991), or stress-induced RBC increase (Tort and Hernandez-Pascual 1990) but also anemic response (Ruparelia et al. 1990; Gill and Epple 1993) in fish. Houston and Keen (1984) suppose that Cd may cause haemolysis by affecting RBC membranes but no such effect was observed in the present study.

White blood cell count (Fig. 3) considerably decreased in cadmium-treated fish after 48 and $96 \mathrm{~h}$ from the end of exposure, compared to control K. K0 value, however, did not significantly differ either from $\mathrm{K} 0$ or from cadmium-exposed groups. This difference rather indicates cadmium-induced WBC decrease than recovery from stress, taking into consideration that 4 out of 10 fish died. Reduction of WBC in cadmium-treated fish was also observed by Ghazaly (1991) and Saxena et al. (1992).

Phagocytic activity (Fig. 4) was significantly $(\mathrm{P}<0.05)$ higher in non-exposed fish than in all remaining groups. In cadmium-treated fish it was initially (Cd0-Cd48) elevated, comparing to control $\mathrm{K}$. This index also indicated manipulation stress in fish. However, the results show that in cadmium-treated fish phagocytic activity initially increased, which might have been a response to damage of other tissues by metal. NBT index decreased after $96 \mathrm{~h}$ to the level of control K, suggesting a suppressed phagocytosis.

Table 1

Viability of lymphocytes (percentage of live lymphocytes)

\begin{tabular}{|l|c|}
\hline Group & Mean \pm S. D. \\
\hline K0 & $91.3 \pm 3.9$ \\
K & $93.5 \pm 5.1$ \\
Cd0 & $94.0 \pm 4.8$ \\
Cd24 & $94.3 \pm 5.0$ \\
Cd48 & $91.0 \pm 2.6$ \\
Cd72 & $94.0 \pm 5.2$ \\
Cd96 & $83.3 \pm 20.2$ \\
\hline
\end{tabular}

In Table 1, mean percentage of live lymphocytes in blood, head and abdominal kidney, and in spleen is shown. Viability of lymphocytes did not show any considerable differences among groups, in all samples exceeding $90 \%$, except CD96 where lowest percentage of live lymphocytes was observed in head kidney $(53 \%)$. The results were not conclusive since only one fish of each group was analyzed but may indicate suppression of immunological function in Cd96 group. Cadmium-induced immunosuppression was observed in vitro by Viola et al. (1989) who noted impairment of NK cells. Thuvander (1989), however, observed higher humoral antibody response in Cd-treated fish.

Only 6 out of 10 cadmium-exposed fish survived $96 \mathrm{~h}$ after the end of the exposure. Short exposure to cadmium strongly affected fish physiology. This, however, was not obvious from blood analysis. Changes observed in blood were typical of stress response, and seemed to be caused not only by cadmium, but also by manipulation.

\section{Změny vybraných krevních parametrů u kapra obecného po akutní intoxikaci kadmiem}

Hematokritová hodnota, počet červených a bílých krvinek, fagocytární index a životaschopnost (viabilita) lymfocytů byly sledovány u kapra obecného po 3hodinové expozici $10 \mathrm{mg} \cdot \mathrm{dm}^{-3} \mathrm{kadmia}$. Hematokrit a počet erytrocytů byl zvýšen u všech ryb vystavených kadmiu a u kontrolních ryb ve srovnání $\mathrm{s}$ rybami nestresovanými, odebranými př́mo $\mathrm{z}$ chovné nádrže. Tyto nálezy potvrzují, že uvedené změny byla 
vyvolány převážně manipulačním stresem, t.j. nebyly pozorovány pouze změny způsobené vlivem kadmia na červené krevní buňky.

Počet bílých krevních buněk byl snížen po 48 a 96 h po skončení expozice kadmiu, což signalizuje imunosupresi.

Fagocytární odpověd byla signifikantně potlačena $(\mathrm{P}<0.05) \mathrm{u}$ všech stresovaných ryb a ukazuje také na kadmiem vyvolané zvýšení do 48 hod po ukončení expozice Cd. Později bylo pozorováno snížení.

Předběžné výsledky životaschopnosti lymfocytů signalizují určitou supresi po 96 hod. Pouze 6 z 10 ryb přežilo 96 hod po skončení expozice, což indikuje narušení fyziologických funkcí, které se prímo neodrazily v jejich krevním obraze.

\section{References}

DOJLIDO, J. R. 1995: Chemia wód powierzchniowych. "Ekonomia i Srodowisko", 342 p.

GHAZALY, K. S. 1992: Hematological and physiological responses to sublethal concentrations of cadmium in a freshwater teleost, Tilapia zilii. Water, Air, and Soil Pollution 64: 551-559

GILL, T. S., EPPLE, A. 1993: Stress-related changes in hematological profile of the American eel (Anguilla rostrata). Ecotox. Environ. Safety 25: 227-235

HOUSTON, A. H., KEEN, J. E. 1984: Cadmium inhibition of erythropoiesis in goldfish, Carassius auratus. Can. J. Fish. Aquat. Sci. 41: 1829-1833

RUPARELIA, S. G., VERMA, Y., SAIYED, S. R., RAWAL, U. M. 1990: Effect of cadmium on blood of tilapia, Oreochromis mossambicus (Peters), during prolonged exposure. Bull. Environ. Contam. Toxicol. 45: 305-312

SARAVANAN, T. S., NATARAJAN, M. 1991: Hematological parameters as indicators of metallic stress in Anabas testudineus. J. Ecotoxicol. Environ. Monit. 1: 365-369

SAXENA, M. P., GOPAL, K., JONES, W., RAY, P. K. 1992: Immune responses to Aeromonas hydrophila in cat fish (Heteropneustis fossilis) exposed to cadmium and hexachlorocyclohexane. Bull. Environ. Contam. Toxicol. 48: 194-201

THUVANDER, A. 1989: Cadmium exposure in rainbow trout Salmo gairdneri Richardson: effects on immune function. J. Fish Biol. 35: 521-529

TORT, L., HERNANDEZ-PASCUAL, M. D. 1990: Haematological effects in dogfish (Scyliorhinus canicula) after short-term sublethal cadmium exposure. Acta hydrochim. Hydrobiol. 18: 379-383

VIOLA, A., PREGNOLATO, G., ALBERGONI, V. 1966: Effects of in vitro cadmium exposure on natural killer (NK) cells of catfish, Ictalurus melas. Fish and Shellfish Immunology 6: 167-172 